\title{
Detection of Multidrug-Resistance Gram-Negative Bacteria from Hospital Sewage in North East, Nigeria
}

\author{
Adam Mustapha ${ }^{1,2, *}$, Turgut Imir ${ }^{1}$ \\ ${ }^{1}$ Department of Medical and Clinical Microbiology, Faculty of Medicine, Near East University, Nicosia, North Cyprus \\ ${ }^{2}$ Department of Microbiology, Faculty of Science, University of Maiduguri, Maiduguri, Nigeria
}

Email address:

Adadmustapha@gmail.com (A. Mustapha)

${ }^{*}$ Corresponding author

To cite this article:

Adam Mustapha, Turgut Imir. Detection of Multidrug - Resistance Gram-Negative Bacteria from Hospital Sewage in North East, Nigeria. Frontiers in Environmental Microbiology. Vol. 5, No. 1, 2019, pp. 1-7. doi: 10.11648/j.fem.20190501.11

Received: December 4, 2018; Accepted: January 18, 2019; Published: February 22, 2019

\begin{abstract}
Antibiotic resistance is on the verge of becoming top killer globally if left unattended in few decades to come. Much focus has been on clinical use and misuse of antibiotics and non-therapeutic applications in agriculture are blamed for the emergence of resistance. However, the rising incident of environmental spread of antibiotic is a major public health concern. The purpose of this study is to investigate the occurrence of gram-negative bacteria from hospitals sewage and evaluate the multi-drug resistant pattern of the isolates in the study area. Sample from five government's hospitals in Damaturu, Northern Nigeria were collected. The bacteria were quantified using pour plating method; colonies were counted and further characterized by morphological and biochemical characteristics using standard microbiological techniques. Antibiotic sensitivity testing was determined by Kirby-Baur disc diffusion method. A total of 1377 gram-negative isolates were identified; Escherichia coli (331, 24.0\%), Salmonella enteric (187, 13.5\%), Pseudomonas aeruginosa (113, 8.20\%), Proteus mirabilis (69, 5.01\%), Klebsiella pneumoniea (271, 19.6\%), Vibrio cholera (89, 6.4\%), Morganella morganii (77, 5.59\%), Shigella species $(201,14.5 \%)$, Citrobacter fruendii (51,3.70\%) and Moraxella catarrhalis (48, 3.48\%). The Multiple Antibiotic Resistance (MAR) index was calculated, and found that all the isolates were multi-drug resistant except Morganella morganii. The MARI exhibited by the isolates ranged from 0.2 to $1.0 \%$. Escherichia coli was leading resistant isolate $(100 \%)$ to the ten antibiotics tested, while other isolates studied exhibited resistance to at least three or more antibiotics tested. Resistance was highest to Nalidixic acid (100\%) and lowest with Ciprofloxacin and Augmentin ( $30 \%$ each). This study found multi-drug resistance gram-negative bacteria of both clinical and public health importance, thus hospital sewage housed antibiotic resistant bacteria and aids the spread in environment. Further research will look at the molecular characterization of the antibiotic resistant genes in the study area.
\end{abstract}

Keywords: Hospital Sewage, Gram Negative, Multiple Antibiotic Resistance Index (MARI), Environmental Isolates

\section{Introduction}

There is projection that infections related to antibiotic resistant organisms will contribute to over 10million deaths annually by 2050 worldwide with great economic loss, if the menace is not halted [1]. Furthermore, the slow nature of discovery of new antibiotics has put the public health in a danger [2-5]. The use of antibiotic is being challenged due to the emergence of new infectious diseases and resurgence of many infections that have been treated and the recent increase in bacterial resistance in organisms of public and clinical importance [6]. Antibiotic resistance is as old as the antibiotic but the sudden increase in the development and spread of the resistant genes are of great concern. Indiscriminate use of antibiotics for medical purposes, failure of patients to complete prescription and use of antibiotics for other purposes have been recognized as a cause for development and spread of antibiotic resistant bacteria [7].

Over the years, there is shift in paradigm in antibiotic resistant organisms from gram positive to gram negative bacteria. For instance infection with methecillin resistant Staphyloccocus aureus has been declining due to hospital infection control but there is a rising trend in resistance by 
Escherichia coli, Klebsiella species and other gram-negative bacteria [8]. The last resort for critically ill patient with multidrug resistance gram negative infection, colistin has been on verge of becoming less effective against $E$. coli and other gram-negative bacteria [9-11]. Regardless of the source, bacterial resistance is a cause for concern as there have been reports of crossing resistance from one species to another, also from one environment to another. This phenomenon could be possible via mobile genetic elements such as plasmids and transposons horizontally [12-14]. Bridget et al. [15] assayed microorganisms and observed recurrent conjugative transfer of resistant genes. They found that more than $83 \%$ of their environment isolates had exchanged one or more resistant genes. Shakibaie et al. [16] observed the horizontal transfer of resistant genes by conjugation from Pseudomonas aeruginosa to E. coli. It is clear that the environment allows the proximity of transfer of resistant genes among bacterial isolates which can be disseminated further to sensitive bacteria.

There has been much focus on resistance from clinical isolates, until recently that environmental isolates have become centre of attention. Environment, especially water environment serves as a pool for antibiotic, antibiotic resistant bacteria and their genes. An important source is clinical sewage, where discharge from various units can allow exchange between different bacterial populations. Furthermore, discharge from health institutions into larger water receiving bodies may lead to further spread of antibiotic resistance. The high microbial content and discharge of antibiotics at sub-therapeutic concentrations in sewage may influence selection of resistance [17-20]. A number of researches have assessed the occurrence of antibiotic resistance patterns of hospital sewage isolates in different parts of the world. Brennan and Everman [21] found reduced susceptibility by $E$. coli isolated from sewage in treatment facilities in Oklahoma which attributed to the accumulation of resistant genes in the environment. Similar studies have reported high occurrence of antibiotic resistant bacteria [22-26]. All the authors revealed high burden of clinically significant antibiotic resistant bacteria (ARB), most with multi-drug resistant ability and tagged the ARB as "environmental pollutants".

Despite the ample studies on this, there is little in Nigeria, particularly Northern Nigeria to the best of our knowledge. Therefore, this study aimed to isolate gram-negative bacteria and their resistance pattern from hospital sewage in major hospitals in Damaturu, Yobe, Nigeria. This will contributes to the global survey of antibiotic resistance and data collection.

\section{Materials and Methods}

\subsection{Sampling Site and Procedure}

The research design was carried out in 5 hospitals in
Damaturu and environs, geographical coordinates are $11^{\circ} 44^{\prime} 55^{\prime \prime N o r t h}, 1^{\circ} 57^{\prime} 50^{\prime \prime E a s t . ~ T h e ~ s a m p l i n g s ~ w e r e ~}$ performed between the months of June and August, 2018. Hospital sewage samples $(400 \mathrm{ml})$ were collected in each hospital and transported to the laboratory in not later than 2 hours. The physical characteristics of the samples were taken in were clear with some particulates, and then were mixed up on arrival to the laboratory.

\subsection{Bacterial Isolation and Identification}

Serial dilutions of the bacterial suspensions were made to reduce the bacterial colonies to obtain pure colonies. Using the pour plate method, each sample dilution was poured on nutrient agar (Sigma-Aldrich) and incubated at $37^{\circ} \mathrm{C}$ for 24 hours. Colony count was made and distinct colonies from each nutrient plate were sub-cultured separately on MacConkey agar (Sigma-Aldrich) and incubated at $37^{\circ} \mathrm{C}$ for 24hours. Furthermore, the bacterial isolates were characterized according to morphological characteristics and biochemical tests, and identified using the guidelines of Bergey's Manual of Determinative Bacteriology [27].

\subsection{Antibiotic Susceptibility Testing}

All of the bacterial isolates identified were subjected to antibiotic susceptibility screening based on Kirby-Baur disc diffusion method [28]. The antibiotic impregnated disc containing the following; Tarivid (OFX) 10 $\mu \mathrm{g}$; Reflacine

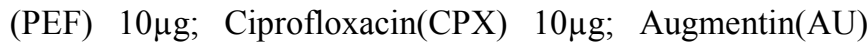

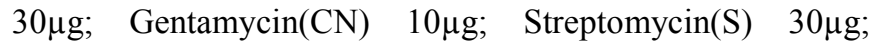

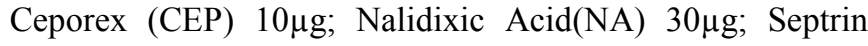

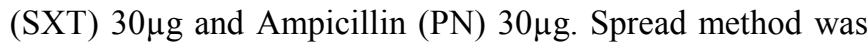
used, where each of the identified isolates were spread on Muller-Hilton agar, and the discs were placed and incubated at $37^{\circ} \mathrm{C}$ for 24 hours. Zones of inhibition were measured $(\mathrm{mm})$ and classified as resistant(R), intermediate (I) or sensitive(S) in accordance with the standard set by Clinical Laboratory Standards Institute (CLSI) guidelines [29].

\section{Results}

\subsection{Bacterial Count of the Isolates}

The result of colony forming units ranged from $2.73 \times 10^{3} / \mathrm{ml}$ to $4.21 \times 10^{3} / \mathrm{ml}$ colonies. A total of 1377 gramnegative bacteria were recovered and bacteriological analysis identified the following Escherichia coli (331, 24.0\%), Salmonella enteric $(187,13.5 \%)$, Pseudomonas aeruginosa (113, 8.20\%), Proteus mirabilis (69, 5.01\%), Klebsiella pneumoniae (271, 19.6\%), Vibrio cholera (89, 6.4\%), Morganella morganii (77, 5.59\%), Shigella species (201, $14.5 \%)$, Citrobacter fruendii $(51,3.70 \%)$ and Moraxella catarrhalis $(48,3.48 \%)$ (Figure 1). 


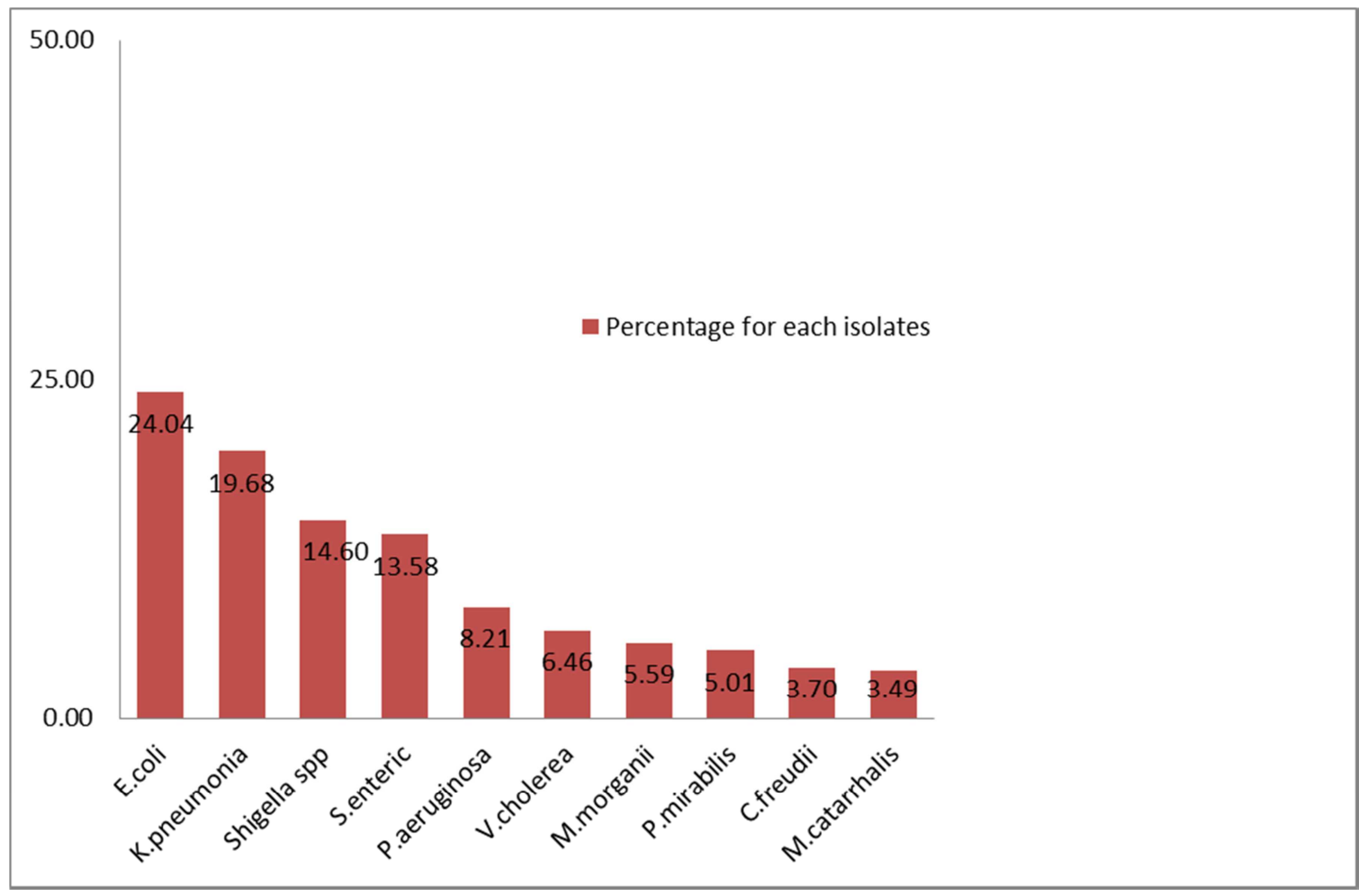

Red bars represent percentage of each bacterium of the total isolates (1377).

Figure 1. Frequency of the gram-negative bacteria identified.

\subsection{Antibiotic Susceptibility Test}

The result of antimicrobial susceptibility test on isolates obtained is presented by measuring the zones of inhibition around each antibiotic disc; each value is a mean of triplicate measurement (Table 1). Intermediates isolates were considered as resistant to all the agents tested.

Table 1. Zone of Inhibition Shown by the Bacterial Isolates.

\begin{tabular}{|c|c|c|c|c|c|c|c|c|c|c|}
\hline \multirow{2}{*}{ Identified Isolate } & \multicolumn{10}{|c|}{ Zone of Inhibition (mm) } \\
\hline & OFX & PEF & CPX & $\mathbf{A U}$ & GN & $\mathbf{S}$ & CEP & NA & SXT & PN \\
\hline E.coli & 10 & 16 & 14 & 11 & 13 & 10 & 20 & 10 & 12 & 11 \\
\hline M. catarrhalis & 20 & 22 & 22 & 28 & 28 & 20 & 14 & 16 & 11 & 15 \\
\hline S.enteric & 21 & 24 & 23 & 25 & 12 & 11 & 15 & 10 & 16 & 13 \\
\hline P. aeruginosa & 14 & 16 & 23 & 26 & 19 & 12 & 12 & 13 & 15 & 20 \\
\hline K. pneumoniae & 13 & 15 & 21 & 23 & 16 & 15 & 20 & 19 & 15 & 12 \\
\hline P. mirabilis & 14 & 15 & 15 & 15 & 12 & 14 & 20 & 17 & 16 & 18 \\
\hline V. cholera & 26 & 22 & 21 & 14 & 12 & 18 & 22 & 18 & 19 & 13 \\
\hline C. fruendii & 21 & 14 & 23 & 25 & 28 & 11 & 14 & 16 & 14 & 17 \\
\hline M. morganii & 19 & 28 & 28 & 21 & 24 & 23 & 27 & 11 & 22 & 11 \\
\hline Shigella spp & 18 & 21 & 15 & 18 & 21 & 17 & 22 & 14 & 15 & 13 \\
\hline
\end{tabular}

Legend: OFX=Tarivid; PEF=Reflacine; $\mathrm{CPX}=$ Ciprofloxacin; $\mathrm{AU}=$ Augmentin; $\mathrm{GN}=$ Gentamycin; $\mathrm{S}=$ Streptomycin; $\mathrm{CEP}=\mathrm{Ceporex}$; NA=Nalidixic Acid; SXT=Septrin; PN=Ampicillin.

\subsection{Determination of Multiple Antibiotic Resistance Index (MARI)}

MARI was calculated using the formular, MARI $=\mathrm{a} / \mathrm{b}$ where "a" is the number of antibiotic resisted and " $\mathrm{b}$ " is the total number of antibiotic used in the study [5]. Isolate with MARI value of $0.2>$ is suggests multiple antibiotic resistant bacteria and indicate presence of highly resistant bacteria. The MARI exhibited by the isolates ranged from 0.2 to $1.0 \%$. MAR phenotypes of isolates that exhibited resistances to three or more antibiotics were generated (Table 3).

Most of the isolates were resistant to more than three antibiotics, except M. morganii. All the isolates were resistant to NA and among the isolates, E. coli showed complete resistant $(100 \%)$ to all the antibiotics, followed by P. aeruginosa and P. mirabilis $(70 \% \mathrm{e}$ ach), K. pneumoniae (60\%), C. fruendii and S. enteric (50\% each), M. catarrhalis, $V$. cholera and Shigella spp (40\% each) while Morganella morganii (20\%) showed the least resistance to the respective antibiotics used. The other isolates exhibited resistant to at 
least two or more antibiotics (Table 1). The isolates were

(S) and counted the intermediate as resistant (Table 2). classified into resistant (R), intermediate (I) and susceptible

Table 2. Resistance Pattern of Isolates to the Respective Antibiotics used.

\begin{tabular}{|c|c|c|c|c|c|c|c|c|c|c|}
\hline \multirow{2}{*}{ Identified Isolates } & \multicolumn{10}{|c|}{ Resistance Pattern } \\
\hline & OFX & PEF & CPX & $\mathbf{A U}$ & GN & $\mathbf{S}$ & CEP & NA & SXT & $\mathbf{P N}$ \\
\hline E.coli & $\mathrm{R}$ & $\mathrm{R}$ & $\mathrm{R}$ & $\mathrm{R}$ & $\mathrm{R}$ & $\mathrm{R}$ & $\mathrm{R}$ & $\mathrm{R}$ & $\mathrm{R}$ & $\mathrm{R}$ \\
\hline M.catarrhalis & $\mathrm{S}$ & $\mathrm{S}$ & $\mathrm{S}$ & $\mathrm{S}$ & $\mathrm{S}$ & $\mathrm{S}$ & $\mathrm{R}$ & $\mathrm{R}$ & $\mathrm{R}$ & I \\
\hline S.enteric & $\mathrm{S}$ & $\mathrm{S}$ & S & S & $\mathrm{R}$ & $\mathrm{R}$ & $\mathrm{R}$ & $\mathrm{R}$ & $\mathrm{S}$ & $\mathrm{R}$ \\
\hline P.aeruginosa & I & $\mathrm{S}$ & S & S & I & $\mathrm{R}$ & $\mathrm{R}$ & $\mathrm{R}$ & $\mathrm{R}$ & $\mathrm{R}$ \\
\hline K. Pneumoniea & I & I & $\mathrm{S}$ & $\mathrm{S}$ & $\mathrm{S}$ & $\mathrm{S}$ & $\mathrm{R}$ & I & $\mathrm{R}$ & $\mathrm{R}$ \\
\hline P.mirabilis & $\mathrm{R}$ & I & $\mathrm{R}$ & $\mathrm{R}$ & $\mathrm{R}$ & I & $\mathrm{S}$ & I & $\mathrm{S}$ & $\mathrm{S}$ \\
\hline C.fruendii & $\mathrm{S}$ & I & $\mathrm{S}$ & $\mathrm{S}$ & S & $\mathrm{R}$ & $\mathrm{R}$ & I & $\mathrm{R}$ & $\mathrm{S}$ \\
\hline M.morganii & $\mathrm{S}$ & $\mathrm{S}$ & $\mathrm{S}$ & $\mathrm{S}$ & $\mathrm{S}$ & $\mathrm{S}$ & $\mathrm{S}$ & $\mathrm{R}$ & $\mathrm{S}$ & $\mathrm{R}$ \\
\hline Shigella spp & $\mathrm{S}$ & $\mathrm{S}$ & $\mathrm{R}$ & $\mathrm{S}$ & $\mathrm{S}$ & $\mathrm{S}$ & $\mathrm{S}$ & $\mathrm{R}$ & $\mathrm{R}$ & $\mathrm{R}$ \\
\hline
\end{tabular}

$\mathrm{R}=$ resistant; $\mathrm{I}=$ intermediate; $\mathrm{S}=$ susceptible.

The resistance antibiogram was measured to express the level of effectiveness of the drugs to the isolates. Resistance was highest to NA (100\%) and lowest with CPX and AU (30\% each). An isolate can be considered multidrug resistance when it resistant to three or more antibiotics, and nine (9) of the isolates had resistance range between 3-10 antibiotics (Table 3).

Table 3. Multiple drug resistance indexes (MARI) of the isolates.

\begin{tabular}{|c|c|c|c|}
\hline Isolates & List of antibiotics & Number of antibiotics & MARI \\
\hline E.coli & OFX, PEF, CPX, AU, GN, S, CEP, NA, SXT, PN & 10 & 1 \\
\hline M.catarrhalis & CEP, NA, SXT, PN & 4 & 0.4 \\
\hline S.enteric & GN, S, CEP, NA, PN & 5 & 0.5 \\
\hline P.aeruginosa & OFX, S, CEP, NA, SXT, GN, PN & 7 & 0.7 \\
\hline K. Pneumoniea & CEP, SXT, PN, OFX, PEF, NA & 6 & 0.6 \\
\hline P.mirabilis & OFX, CPX, AU, GN, PEF, S, NA & 7 & 0.7 \\
\hline V.cholelea & $\mathrm{AU}, \mathrm{GN}, \mathrm{PN}, \mathrm{NA}$ & 4 & 0.4 \\
\hline C.fruendii & S, CEP, SXT, PEF, NA & 5 & 0.5 \\
\hline M.morganii & NA, PN & 2 & 0.2 \\
\hline Shigellaspp & CPX, NA, SXT, PN & 4 & 0.4 \\
\hline
\end{tabular}

\section{Discussion}

Profiles of bacterial population in different environments have been reported worldwide. In addition, the resistance profiles of such bacteria have been studied [30-34]. This study focuses to investigate the members of gram-negative bacteria from hospital sewage and their resistance profile to the most commonly used antibiotics in the study area. Previous studies shown that gram-negative bacteria are highly associated with hospital infections and are detected in sewage [35-37]. Furthermore, studies have been reported in similar environment that allow discharge of antibiotics waste into receiving water body, for instance occurrence of antibiotic resistant superbugs from pharmaceutical company which indicated heavy resistance burden in the isolates [31]. Though assessment of resistance profile of bacterial associated with hospital sewage source have been reported in Southern part of Nigeria $[36,38,39]$, but there is little or no data available on the hospital sewage isolates and resistance status in Northern Nigeria.

In the present study, sewage pool from different units of the hospitals was assessed for the presence of gram-negative bacteria and their susceptibility. The results found that high bacteria count was in sewage; one possible explanation to this scenario is that the bacteria get concentrated at the sludge and create favorable condition for growth. By implication, discharging such sewage get into large water receiving bodies without proper treatment could further allow dissemination of bacterial resistance isolates. High bacterial counts from hospital sewage and effluents are also reported [33]. Lein et. al. [40] confirmed the presence of bacteria resistant from hospital wastewater pre-treatment and posttreated wastewater, thus rise concern about the efficacy of wastewater treatment in eliminating antibiotic resistant bacteria. This has serious threat to public health and could play role in further spread of antibiotic resistance.

This study found high prevalence of multidrug resistant bacteria to the antibiotics tested. The study observed varying degree of multidrug resistance amongst the isolates except $M$. morganii. Similar occurrences of resistant gram-negative bacteria have been reported in hospital effluents [34, 41-43]. Here, it was found that $E$. coli had the highest resistance to the all drugs tested $(100 \%)$, this could be attributed to the abundance nature of $E$. coli in environment and its easy adaptability. Similar trend of high resistance pattern of $E$. coli from hospital sewage was reported [30, 33, 43-44]. In this present study, least resistance by Morganella morganii (20\%) was observed. M. morganii are intrinsically resistant to members of beta-lactam but are known to be susceptible to 
large group of antibiotics such as fluoroquinolones (ciprofloxacin), aminoglycosides, chloramphenicol, cephalosporins, aztreonam [45]. In this study, other isolates that exhibited multidrug resistance are $P$. mirabilis and $K$. pneumoniae (70\% each), S. enteric (60\%), C. fruendii (50\%), and Vibro cholera (40\%). Interestingly, the resistance pattern of $P$. aeruginosa $(70 \%)$ in this study, is in agreement with other reports [17, 46-48]. In contrast, Elmanama et. al. [17] reported high susceptibility of $P$. aeruginosa from environmental source than clinical isolates. In the current study, results also found isolates of significant health importance that show high degree of multidrug resistance and analysis of the MAR index of isolates showed that most of the isolates had MARI of $>0.2$, this serves as a pointer to high use of antibiotics in such environments. The high rates of resistance by these isolates in this study agreed with the previous studies [42, 49-52]. These isolates should raise concern as they play role in many hospital infections.

In the present study, the type of antibiotic that was highly resisted was Nalidixic acid $(100 \%)$ while Ciprofloxacin and Augmentin (30\% each) show high efficacy on the isolates tested (Table 1). Several studies reported NA resistance, for instance Michael et. al. [53] reported decreased susceptibility to NA by Salmonella species, others reported in various species [54-55].

Attempts have been made to measure the concentration of antibiotics in hospitals sewage since they are continuously release into wastewater chamber [40, 56-57]. The authors reported presence of most commonly prescribed antibiotics and this encourages selective pressure in bacterial community to become resistant. Selection of resistant bacteria is made possible by the low concentration of antimicrobials in the wastewater-which increases their dilution thereby reducing their strength $[6,58]$. Though, this study could not establish direct link of hospital sewage isolates which are potential pathogens to human but there is concern that not all isolates are completely removed during treatments, hence discharge of the hospital sewage could facilitate dissemination of antibiotic resistant organisms into environments.

Although, the study identified number of important pathogens and their resistance pattern, the isolates are not representatives of all gram-negative bacteria as well as other bacteria, for the fact that there exist some even un-culturable bacteria. Also, the sample collection could not differentiate individual units of the hospitals to access which organism is likely to be in the sewage.

\section{Conclusion}

The results of this study reveal the occurrence of high level of multidrug resistance gram-negative bacteria in hospital sewage from the study area, this posses the concern of spread of antibiotic resistance in healthcare environment and ultimately to larger water receiving body. The results obtained in this study are in similar trend in many part of the world, however this provide new data of resistance pattern of isolates from hospital sewage in Northern Nigeria, hence contributes to the efforts of collecting more data for surveillance and monitoring of antibiotic resistance globally. Further study is recommended to detect molecular characterization of antibiotic resistant genes in the study area.

\section{References}

[1] DeKraker, M. E., Stewardson, A. J., Harbarth, S. (2016). Will 10 Million People Die a Year due to Antimicrobial Resistance by 2050?. PLoS medicine. 13, 11.

[2] DeKraker, M. E. A., Davey, P. G., Grundmann, H. (2011). Mortality and Hospital Stay Associated with Resistant Staphylococcus aureus and Escherichia coli Bacteremia: Estimating the Burden of Antibiotic Resistance in Europe. PLoS Med. 8:e1001104.

[3] Fair, R. J. and Tor, Y. (2014). Antibiotics and bacterial resistance in the $21^{\text {st }}$ century. Perspectives in medicinal chemistry. 6, 25-64.

[4] O'Neill, J. (2014). Review on Antimicrobial Resistance Antimicrobial Resistance: Tackling a crisis for the health and wealth of nations. London: Review on Antimicrobial Resistance.

[5] Abat, C. J. M., Rolain, G., Dubourg, P. E., Fournier, H., Chaudet, D. R. (2017) Evaluating the clinical burden and mortality attributable to antibiotic resistance: the disparity of empirical data and simple model estimations. Clinical Infectious Disease. S58-S63.

[6] Mubbunu, L., Siyumbi, S., Katango, C., Mwambungu, A. (2014) Wastewaters as reservoir of antibiotic Resistant microorganism: A case of Luanshya wastewaters ponds. International Journal of Research in Medical and Health Sciences. 4(9):15-20.

[7] Aminov, R. I. (2009). The role of antibiotics and antibiotic resistance in nature. Environmental Microbiology. 11(12):2970-2988.

[8] Exner, M., Bhattacharya, S., Christiansen, B., Gebel, J., Goroncy-Bermes, P., Hartemann, P., Heeg, P., Ilschner, C., Kramer, A., Larson, E., Merkens, W., Mielke, M., Oltmanns, P., Ross, B., Rotter, M., Schmithausen, R. M., Sonntag, H. G., Trautmann, M. (2017). Antibiotic resistance: What is so special about multidrug-resistant Gram-negative bacteria? GMS hygiene and infection control, 12, Doc05. doi: 10.3205/dgkh000290.

[9] Caniaux, I., Belkum, A. V., Zambardi, G., Poirel, L., Gros, M. F. (2016). MCR: modern colistin resistance. Eur J Clin Microbiol Infect Dis. DOI10.1007/s10096-016-2846-y.

[10] Hashemi, M. M., Rovig, J., Weber, S., Hilton, B., Forouzan, M. M., Savage, P. B. (2017). Susceptibility of ColistinResistant, Gram-Negative Bacteria to Antimicrobial Peptides and Ceragenins. Antimicrobial Agents and Chemotherapy. 61(8):e0029217.

[11] MacNair, C. R., Stokes, J. M., Carfrae, L. A., Fiebig-Comyn, A. A., Coombes, B. K., Mulvey, M. R., Bron, E. D. (2018). Overcoming mcr-1 mediated colistin resistance with colistin in combination with other antibiotics. Nature Communication. 9 (1):458. doi: 10.1038/s41467-018-02875-z. 
[12] Birosova, L., and Mikulasova', L. (2009). Development of triclosan and antibiotic resistance in Salmonella enteric serovar Typhimurium. Journal of Medical Microbiology .58, 436-471.

[13] Lázár, V. (2014). Genome wide analysis captures the determinants of the antibiotic cross-resistance interaction network. Nat. Commun. 5, 4352 doi: 10.1038/ncomms5352.

[14] Rozos, G., Voidarou, C., Stavropoulou, E., Skoufos, I., Tzora, A., Alexopoulos, A., Bezirtzoglou, E. Biodiversity and Microbial Resistance of Lactobacilli Isolated From the Traditional Greek Cheese Kopanisti. Front. Microbiol. 9 (517): doi: 10.3389/fmicb.2018.00517.

[15] Bridgett, P., Daniel, C., Steven, F. (2010). Antibiotic Resistance, gene transfer and water quality patterns observed in waterways near Confined Animal Feeding Operations farms and wastewater treatment facilities. Water, air, soil, pollution, Dol10.1007/11270-010-0602-y.

[16] Shakibaie, M. R., Jalilzadeh, K. A., Yamakanamardi, S. M. (2009) Horizontal transfer of antibiotic resistance genes among gram negative bacteria in sewage and lake water and influence of some physico-chemical parameters of water on conjugation process. Journal of Environmental Biology. 30, 45-49.

[17] Elmanama, A. A., Elkichariu, A. Y., Mohsin, M. (2006). Contribution of hospital wastewater to the spread of antibiotic resistance in comparison to non-health institution. Journal of AL-Aqsa University. 10, 108-121.

[18] Martinez, J. L. (2009). Environmental pollution by antibiotics and by antibiotic resistance determinants. Environmental Pollution.157, 2893-2902.

[19] Wellington, E. M. H., Boxall, A. B. A., Cross, P., Feil, E. J., Gaze, W. H., Hawkey, P. M., Johnson-Rollings, A. S., Jones, D. L., Lee, N. M., Otten, W., Thomas, C. M., Williams, A. P. (2013). The role of the natural environment in the emergence of antibiotic resistance in Gram-negative bacteria. Lancet Infect Dis. 13, 155-165.

[20] Aali, R., Nikaeen, M., Khanahmad, H., Hassanzadeh, A. (2014). Monitoring and comparison of antibiotic resistant bacteria and their resistance genes in municipal and hospital wastewaters. International journal of preventive medicine. 5 (7):887-894.

[21] Brennan, R. E, and Everman, S. (2012). Antibiotic resistance of Escherichia coli isolated from a stream near two wastewater treatment facilities in Edmond, Oklahoma. Proceeding of the Oklhoma Academy of Science. 92, 59-64.

[22] Kolár̆, M., Urbánek, K., and Látal, T. (2001). Antibiotic selective pressure and development of bacterial resistance. International Journal of Antimicrobial Agents. 17 (5):357363.

[23] Ibrahim, M. K., Abdel-Moneim, M. G., ldriss, M. A., AlZhrany, T. D. (2010). Antibiotic resistance in Gram-negative pathogenic bacteria in hospitals' drain in Al-MadinaAlMunnawara. Journal of Taibah University for Science. 3, 1422.

[24] Rizzo, L., Manaia, C., Merlin, C., Schwartz, T., Dagot, C., Ploy, M. C. (2013). Urban wastewater treatment plants as hotspots for antibiotic resistant bacteria and genes spread into the environment: a review. Sci. Total Environ. 447, 345-360.
[25] Hocquet, D., Muller, A., Bertrand, X. (2016). What happens in hospitals does not stay in hospitals: antibiotic-resistant bacteria in hospital wastewater systems. Journal of Hospital Infection. doi: 10.1016/j.jhin.2016.01.010.

[26] RodriguezMozaz, S., Chamorro, S.; Marti, E., Huerta, B., Gros, M., Sànchez-Melsió, A. (2015). Occurrence of antibiotic and antibiotic resistance genes in hospital and urban wastewaters and their impact on the receiving griver. Water Res. 69, 234-242.

[27] Bergey, D. H. and Holt, J. G. (1994). Bergey's manual of determinative bacteriology.

[28] Bauer, A. W., Kirby, W. M., Sherris, J. C., Turck, M. (1966). Antibiotic susceptibility testing by a standardized single disk method. American Journal of Clinical Pathology. 45(4):493-496.

[29] Clinical Laboratory Standards Institute (2014). Performance Standards for Antimicrobial Susceptibility Testing; $24^{\text {th }}$ informational supplement, M110-S24; Clinical and Laboratory Standards Institute: Wayne, PA, USA.

[30] Yang, C., Lin, M., Liao, P., Yeh, H., Chang, B., Tang, T., Cheng, C., Sung, C., Liou, M. (2009). Comparison of antimicrobial resistance patterns between clinical and sewage isolates in a regional hospital in Taiwan. Letters in Applied Microbiology. 48, 560-565.

[31] Li, D., Yu, T., Zhang, Y., Yang, M., Li, Z., Liu, M., Qi, R. (2010). Antibiotic Resistance Characteristics of Environmental Bacteria from an Oxytetracycline Production Wastewater Treatment Plant and the Receiving River. Applied and Environmental Microbiology. 76(11):3444-3451.

[32] Lien, L. T. Q., Lan, P. T., Chuc, N. T. K., Hoa, N. Q., Nhung, P. H., Thoa, N. T. M., Diwan, V., Tamhankar, A. J., Stålsby, L. C. (2017). Antibiotic Resistance and Antibiotic Resistance Genes in Escherichia coli Isolates from Hospital Wastewater in Vietnam. Int. J. Environ. Res. Public Health. 14 (7): 699. doi: 10.3390/ijerph14070699.

[33] Le, T. H., Ng, C., Chen, H., Yi, X. Z., Koh, T. H., Barkham, T. M. S., Gin, K. Y. H. (2016). Occurrences and Characterization of Antibiotic-Resistant Bacteria and Genetic Determinants of Hospital Wastewater in a Tropical Country. Antimicrobial Agents and Chemotherapy. 60(12):7449-7456.

[34] Wang, Q., Wang, P., Yang, Q. (2018) Occurrence and diversity of antibiotic resistance in untreated hospitalwater. Science of the Total Environment. 621, 990-999.

[35] Schwartz, T., Kohnen, W., Obst, U. (2003). Detection of antibiotic resistant bacteria and their resistance genes in wastewater, surface water and drinking water biofilms. FEMS Microbiology Ecology. 43, 325-335.

[36] Bolaji, A. S., Akande., I. O., Iromini, F. A., Adewoye, S. O, Opasola, O. A. (2011). Antibiotic resistance pattern of bacteria spp isolated from hospital wastewater in Ede South Western, Nigeria. European Journal of Experimental Biology. 1(4):66-71.

[37] Pandey, A., Afsheen, A. F., Tiwari, S. K. (2011). Isolation and characterization of multidrug resistance cultures from wastewater. Journal of Pharmaceutical and Biomedical Sciences. 13(14):1-7.

[38] Chioma, N., and Obi, O. (2018) Environmental risk assessment of hospital wastewater in Federal Medical Center (FMC), Umuahia, Nigeria. Journal of Environmental Research. 2, 36. 
[39] Obayiuwana, A., Ogunjobi, A., Yang, M., Ibekwe, M. (2018). Characterization of Bacterial Communities and Their Antibiotic Resistance Profiles in Wastewaters Obtained from Pharmaceutical Facilities in Lagos and Ogun States, Nigeria. Int $J$ Environ Res Public Health. 15, 1365. doi: 10.3390/ijerph15071365.

[40] Lien, L. T., Hoa, N. Q., Chuc, N. T., Thoa, N. T., Phuc, H. D., Diwan, V., Dat, N. T., Tamhankar, A. J., Lundborg, C. S. (2016). Antibiotics in Wastewater of a Rural and an Urban Hospital before and after Wastewater Treatment, and the Relationship with Antibiotic Use-A One Year Study from Vietnam. Int $J$ Environ Res and Public Health. 13 (6): 588, doi: 10.3390/ijerph13060588.

[41] Ekhaise, F. O., and Omavwoya, B. P. (2008). Influence of Hospital Wastewater Discharged from University of Benin Teaching Hospital (UBTH), Benin City on Its Receiving Environment. American-Eurasian Journal of Agricultural \& Environmental Sciences. 4, 484-488.

[42] Moges, F., Endris, M., Belyhun, Y., Worku, W. (2014). Isolation and characterization of multiple drug resistance bacterial pathogens from wastewater in hospital and nonhospital environments, Northwest Ethiopia. BMC research notes. 7, 215. doi: 10.1186/1756-0500-7-215.

[43] Rabbani, M. A. G., Howlader, M. Z. H., Kabir, Y. (2017). Detection of multidrug resistant (MDR) bacteria in untreated wastewater disposals of hospitals in Dhaka City, Bangladesh. Journal of Global Antimicrobial Resistance. 10, 120-125.

[44] Sharmin, A., Tonmoy, D., Mohammed, M. H. C. (2018). Multidrug Resistant E. coli in Hospital WasteWater: A Potential Concern for Public Health. Advances in Biotechnology \& Microbiology. 8 (1): doi: 10.19080/ AIBM. 2018.08.555729.

[45] Hauhnar, L., Pachuau, L., Lalhruaitluanga, H. (2018). Isolation and Characterization of Multi-Drug Resistant Bacteria from Hospital Wastewater Sites around the City of Aizawl, Mizoram. Advances in Bioscience and Biotechnology. 9, 311-321.

[46] Slekovec, C., Plantin, J., Cholley, P., Thouverez, M., Talon, D., Bertrand, X. (2012). Tracking down Antibiotic-Resistant Pseudomonas aeruginosa Isolates in a Wastewater Network. PLOSONE. doi.org/10.1371/journal.pone.0049300. 7(12):e49300

[47] Miranda, C. C., De-Filippis, I., Pinto, L. H., Coelho-Souza, T., Bianco, K., Cacci, L. C., Picão, R. C., Clementino, M. M. (2015). Genotypic characteristics of multidrug-resistant Pseudomonas aeruginosa from hospital wastewater treatment plant in Rio de Janeiro, Brazil. J Appl Microbiol., 118 (6): 1276-1286.

[48] Magalhães, M. J., Pontes, G., Serra, P. T., Balieiro, A., Castro, D., Pieri, F. A., Crainey, J. L., Nogueira, P. A., Orlandi, P. P. (2016). Multidrug resistant Pseudomonas aeruginosa survey in a stream receiving effluents from ineffective wastewater hospital plants. BMC Microbiology, 16 (1): 193. doi: 10.11 86/s12866s-016-0798-0.
[49] Okoh, A. I. and Igbinosa, E. O. (2010). Antibiotic susceptibility profiles of some Vibrio strains isolated from wastewater final effluents in a rural community of the Eastern Cape Province of South Africa. BMC Microbiology. 10(143):1-6.

[50] Baron, S., Larvor, E., Chevalier, S., Jouy, E., Kempf, I., Granier, S. A., Lesne, J. (2017). Antimicrobial Susceptibility among Urban Wastewater and Wild Shell fish Isolates of NonO1/Non-O139 Vibrio cholera from LaRance Estuary (Brittany, France). Frontiers in Microbiology. 8, 1637. doi: 10.3389/ fmicb.2017.01637.

[51] Okeyo, A. N., Nontongana, N., Fadare, T. O., Okoh, A. I. (2018). Vibrio Species in Wastewater Final Effluents and Receiving Water shed in South Africa: Implications for Public Health. International journal of environmental research and public health. 15(6):1266. doi: 10.3390/ijerph15061266.

[52] Ziad, D., Jin, F., Elie, S. S., Khalil, E., Elias, D., Khalil, M., Claude, A. R. M., Abdel-Massih, G. M. M. (2018). Multi-drug resistant Enterobacteriaceae in Lebanese Hospital wastewater: Implication in the One Health Concept. Microbial Drug Resistance. 24(2):166-174.

[53] Michael, P. R., Colm, D., Catherine, C. A. (2011). Nalidixic Acid- Resistant Strains of Salmonella Showing Decreased Susceptibility to Fluoroquinolones in the Midwestern Region of the Republic of Ireland Due to Mutations in the gyrA Gene. Journal of Clinical Microbiology. 49(5):2077-2079.

[54] Joaquim, R., Julian, G., Margarita, M. N., Anna, R., Josep, M. S., Francesc, M., Josep, M., Jordi, V. (2002). High prevalence of nalidixic acid resistant, ciprofloxacin susceptible phenotype among clinical isolates of Escherichia coli and other Enterobacteriaceae. Diagnostic Microbiology and Infectious Disease. 42, 257-261.

[55] James, R., Johnson, A. C., Murray, A. G., Maureen, S., Paula, S., Michael, A., Kuskowski, K. E. S (2003). Isolation and Molecular Characterization of Nalidixic Acid-Resistant Extraintestinal Pathogenic Escherichia coli from Retail Chicken Products. Antimicrobial Agents and Chemotherapy. 47(7):2161-2168.

[56] Jaidumrong, T., Bootrak, D., Rongsayamanont, C. (2016). Removal of Antibiotic Residues by Hospital Wastewater Treatment Facilities in Songkhla, Thailand. $5^{\text {th }}$ International Conference on Environmental Engineering, Science and Management The Twin Towers Hotel, Rong Muang, Bangkok, Thailand, May11-13, 2016.

[57] Kulkarni, P., Olson, N. D., Raspanti, G. A., Rosenberg Goldstein, R. E., Gibbs, S. G., Sapkota, A., Sapkota, A. R. (2017). Antibiotic Concentrations Decrease during Wastewater Treatment but Persistat Low Levels in Reclaimed Water. International journal of environmental research and public health. 14(6):668. doi: 10.3390/ijerph14060668.

[58] Kümmerer, K. (2004). Resistance in the environment. Journal of Antimicrobial Chemotherapy, 54(2):311-320. 